\title{
Entrenched Catalonia: A Secessionist Venture Trapped on an Ethno-Political Draw
}

\author{
Adolf Tobeña \\ Department of Psychiatry and Forensic Medicine, Institute of Neurosciences, Universitat Autònoma Barcelona, Barcelona, Spain \\ Email: adolf.tobena@uab.cat
}

How to cite this paper: Tobeña, A. (2018). Entrenched Catalonia: A Secessionist Venture Trapped on an Ethno-Political Draw. Psychology, 9, 460-471.

https://doi.org/10.4236/psych.2018.93028

Received: February 6, 2018

Accepted: March 27, 2018

Published: March 30, 2018

Copyright $\odot 2018$ by author and Scientific Research Publishing Inc. This work is licensed under the Creative Commons Attribution International License (CC BY 4.0).

http://creativecommons.org/licenses/by/4.0/

\begin{abstract}
A lengthily prepared secessionist attempt culminated, in Catalonia, on Autumn of 2017. A Declaration of Independence was approved by the Regional Parliament, the $27^{\text {th }}$ October, and followed by a suspension of the Autonomy Rule, dictated by Central Government, after due permission by Spanish Senate in accordance with the Constitution. This resulted in the destitution of the Regional Government and the dissolution of the Autonomous Parliament. The secessionist movement had demonstrated great force not only by mobilizing huge amounts of followers repeatedly but on elections and challenges perceived as victories against the State. A rise of influence, however, showed by unionist forces both at street demonstrations and on the last Regional election $\left(21^{\text {th }}\right.$. Dec. 2017), has created a situation that appears as an entrenched draw, within a deeply divided society. I discuss here social and economic profiles that distinguish two big segments of Catalan citizenry, in relation to their options in favor of or against secession. Those profiles that can be traced to a recognizable ethno-cultural frontier based on family origins and habitual language may also contribute to enhance current tensions.
\end{abstract}

\section{Keywords}

Secessionism, Nationalism, Autonomy Rule, Catalonia, Ethno-Cultures

\section{Introduction}

A widely announced and lengthily prepared secessionist attempt culminated in Catalonia, through the Autumn of 2017. A formal Declaration of Independence was approved and proclaimed by a tiny majority of the Regional Parliament, the $27^{\text {th }}$ October at the Ciutadella Palace, downtown Barcelona; such proclamation was followed, in a few hours, by suspension of the Autonomy Rule dictated by the Central Government after obtaining the mandatory permission by the Spanish Senate, applying a Constitutional norm. That order resulted in the destitu- 
tion of the Regional Government and the dissolution of the Autonomous Parliament. The ex-President of Catalonia fled then towards Brussels, accompanied by several ministers, and the ex-Vice-President and other members of the deposed Government were called by a High Court, at Madrid, and after a brief enquiry were preventively sent to prison under the accusation of breaking the democratic law and attempted rebellion against the State. These events attracted wide attention across Europe and the entire world because the region had seen a worrying progression of mounting tensions, from the end of that summer, which had been closely followed by the international media (Plate 1).

The eruption of a sustained and vigorous secessionist movement that attained wide popular support to the point of winning a majority of seats at the Regional Parliament, on the elections of September 2015, had been contemplated with puzzlement because it had appeared in a rich European province, without intolerable abuses from Spanish State or deep social inequalities or internal litigations. Despite the plethora of interpretations (Amat, 2015; Barceló-Soler 2013; Boylan, 2015; Crameri 2014, 2015; Griffiths et al., 2015) the dominant feeling had been bewilderment: why did it happen? Why at that time and with such a display of urgency and popular enthusiasm? And why, especially, in that European corner and not in others? The bulk of hurried diagnostic attempts had focused on economic and socio-political factors linked, mostly, to Southern European circumstances: a serious and long economic recession on previous years, irritation with an outstanding level of corruption and malfunctioning of the leading Spanish political parties, weaknesses and rigidities of the old nation-state framework, fragility of the European Union. These factors surely contributed in

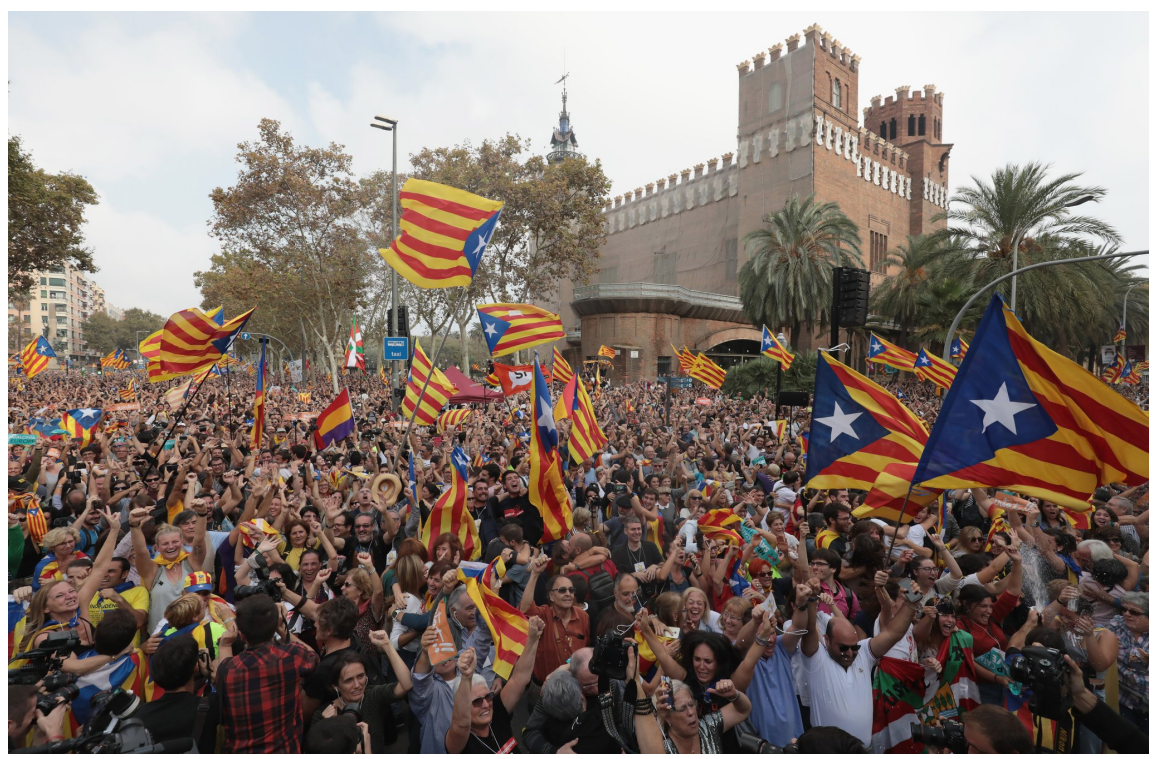

Plate 1. Independence supporters gathered outside the Catalan Parliament in Barcelona, Spain, on Friday $27^{\text {th }}$ October 2017. Credit Jack Taylor/Getty Images (From Raphael Minder and Patrick Kingsley: Spain Dismisses Catalonia Government after Region Declares Independence, The New York Times, October 27, 2017).

https://www.nytimes.com/2017/10/27/world/europe/spain-catalonia-puigdemont.html. 
different degrees, though they left unexplained the specifics of why they had uniquely combined within a single region to the point of igniting massively followed demands for segregation while other Spanish and European regions, with similar problems, were mostly calm.

In a previous paper (Tobeña, 2017) I sustained that there had been an obvious neglect of important psychological vectors at work. The outbreak of powerful movements for conquering long dreamed aspirations of national sovereignty, as it happened in Catalonia, convey ingredients that require a dissection from the psychology of political behaviour. I discussed there a body of findings which pointed mainly towards two factors that had played an important role on the rising wave of demands of self-determination: intensive indoctrination from media platforms linked directly (or indirectly) to the Autonomous Government, and a stubborn and enduring social pressure through monopolizing of the public space with secessionist emblems and signs. I advanced, in fact, that if my depiction was correct, the recent secessionist wave in Catalonia will be remembered as an example of mass indoctrination and social intimidation within a truly democratic context.

\section{Keeping the Non-Secessionists Silent}

In a subsequent essay (Tobeña, 2017a) I widened the description of the role of those and other relevant psychological vectors, within a political confrontation that had erupted among neighbors who had a centuries-old tradition of convivial though tense relationships. A serious litigation that carried characteristic ingredients from societies that contain clear-cut and unsealed ethno-cultural frontiers along which inter-group tensions arise easily.

I also advanced there that a substantial part of the efforts devoted by the secessionist forces towards indoctrination and social intimidation were directed to keep the non-secessionist segment of Catalan citizenry paralyzed and silent. I maintained that (Tobeña, 2017): "the intensity of the indoctrinating pressure applied by the alliance between local media, the agitation campaigns of the pro-secession funds ${ }^{1}$ and the resources devoted by the Regional Government can be explained, in all likelihood, by the never recognized but strong suspicion that the real obstacle for secession was at home. These different actors were perfectly aware of the size of a Catalan citizenry with familial, affective or economic links with Spain and contemplated with apprehension their potential reactions, although that population has remained expectant all along the secessionist wave. There are, in fact, around three millions of Catalan citizens with capacity to intervene in politics who have not been convinced to join the secessionist adven-

${ }^{1}$ ANC: Assemblea Nacional Catalana https://assemblea.cat/; Omnium Cultural https://www.omnium.cat/. The first one, ANC, was created at 2011 and has served as the main engine and network for pro-secession agitation campaigns. The second, OC, is an old trust created to support Catalan culture and language, and entered into secessionist agitation to work along ANC. In addition of financial help by individual supporters both have received backing by Regional Government and many Municipalities. The leaders of both organizations had a prominent role and were the first to be sent, preventively, to jail by a High Court at Madrid, on October 2017. 
ture despite the contextual intimidation that they had to endure. They are very heterogeneous though they predominate in towns that make up the industrial rings of Barcelona and Tarragona's conurbations, as well as in many other suburban neighborhoods and villages across the network of medium-sized towns scattered through the whole region. They have remained stoically silent, without expressing themselves loudly or emphatically through demonstrations or by exhibition of identity signs (the Spanish flag is almost absent in Catalonia), and this may have increased the perception that they constitute a fragmented, submissive and negligible part of the citizenry". I characterized such citizenry as "the crouched and expectant segment" and concluded that to keep them paralyzed "was one of the most important drivers of secessionism urgency. For pro-independence forces, it was mandatory to keep these people silent, demobilized and resigned while the 'window of opportunity for secession' (Griffiths et al., 2015) endured".

Pau Marí-Klose (2015) had described the obvious cleavages that still separate the two larger communities which coexist in Catalonia: native Catalans by descent and many culturally assimilated individuals vs. the long-settled but non-completely assimilated migrants from other Spanish regions plus the more recent waves of Latin-American migrants. The first ones use Catalan language in all professional and living domains, whereas the second ones prefer to use Spanish language, though most of them have also a good instrumental knowledge of Catalan language because education on public schools use Catalan as mandatory first language ${ }^{2}$. Marí-Klose (2015) underlined, however, that studying or openly talking about that kind of social cleavage has been, and still is, a strong taboo within the region.

\section{The Iterated Portrait of a Divided Society}

That cleavage identified a potential breaking line for a social fracture among those civil communities that had not still arrived near to the threshold of an open conflict, despite the visible landscape where a part of the citizenry would gain and the rest would lose in the event of secession. Two successive Regional elections (September 2015; December 2017), two illegal but successfully enacted pseudo-referendums of self-determination in which only the secessionists went to poll stations ( $9^{\text {th }}$ Nov., 2014; $1^{\text {st }}$ Octb. 2017), and a long series of systematic surveys both by C.E.O. (the official survey agency of the Regional Government), and C.I.S (the official survey agency of the Central Government), had repeatedly showed the existence of a sharp political division among Catalan citizens on the issue of a secession from Spain. The fragmentation depicted a society divided in almost two exact segments of secessionists and non-secessionists. Across the whole period 2015-2017, within the C.E.O. regular series of "political barometers", the most direct question "Do you want Catalonia to be an independent

${ }^{2}$ Usos lingüístics de la població de Catalunya: Enquesta 2013, Generalitat de Catalunya: Departament de Cultura,

http://llengua.gencat.cat/web/.content/documents/publicacions/altres/arxius/eulp2013_fullet.pdf. 
state ?", had received "YES" answers, with percentages oscillating between $45 \%$ to $48 \%$; "NO" answers with percentages oscillating between $44 \%$ to $48 \%$, and remnants of $5 \%$ to $10 \%$, of "DON'T KNOW" answers. These surveys are iterated three times per year, at least, using large enough samples ${ }^{3}$.

The regional elections of September $27^{\text {th }}, 2015$, had a turnout of $77.4 \%$ of the electorate $(4,115,807$ of votes cast, from a total of 5,352,786 potential voters): a historical record on such a regional contest. Abstentions were 1.119 .106 (22.56\%) and the sum of blank and null votes were 47,873 (1.16\% of total $)^{4}$. That large turnout was probably the result of an election that was announced as a "plebiscite" for or against secession". A large secessionist coalition ("JuntspelSi": Together for Yes), encompassing the two main nationalist parties and sustained also by the major secessionist funds obtained a total of 1,620,973 votes (39.54\%), getting a clear victory. Adding to that the 336.365 votes (8.2\%) obtained by a radical secessionist formation (CUP, Popular Unity, far left), made a total reach of $1,957,348$ votes in favor of secession (47.8\% of all votes). The sum, on the other hand, of all the votes that went to non-secessionist parties got a total of $2,110,586$ votes (51.28\% of all votes). So, a narrow margin of 150.000 votes separated the unionists (non-secessionists) from the secessionists.

The Regional elections of $21^{\text {th }}$ December 2017 were called by the Spanish Government as a way to terminate, as quickly as possible, with the suspension of the Autonomy Rule dictated two months before. The results ${ }^{6}$ offered again the same portrait of an almost perfectly divided society. This time 4,392,891 citizens went to vote, with the turnout reaching another historical mark of $79.1 \%$ of the electorate (from a census of 5,328,061). Abstentions were 1,161,564 (20.9\%), plus a rest of 35,000 of null or blank votes. The total sum of the secessionist parties reached 2,079,330 votes $(47.33 \%)$, whereas the non-secessionist parties attained $2,227,421$ votes $(50.71 \%)$. So, again the same narrow margin of 150,000 votes gave the leading to the unionists. The leading formation at the Parliament was, however, for the first time in decades, a unionist party: "Citizens" with 1,109,732 voters $(25.5 \%)$ and 36 seats. The political situation resumed the previous standstill because the majority at the Regional Parliament went, once more, to the secessionists parties (70 seats, from a total of 135) due to the characteristics of the electoral law which awards an over-representation to the rural parts of the region.

\section{Unionist Awakening upon the Edge of a Civil Conflict}

The autumn weeks that preceded the "independence declaration" on $27^{\text {th }}$ Octo-

${ }^{3}$ The C.E.O. Barometer of Political Opinion, February 2018

(http://ceo.gencat.cat/ca/barometre/detall/index.html?id=6508), provided, for the first time in years, a noticeable gap between those who responded "YES" (40.8\%) for Catalan independence, versus those responding "NO" (53.9\%), with a remnant of 5.3\% (Don't know). Such tendency towards a potential dissolution of a long draw needs confirmation.

${ }^{4}$ http://governacio.gencat.cat/ca/pgov_ambits_d_actuacio/pgov_eleccions/pgov_dades_electorals/res ultats-2/?a=a\&id_eleccions=A20151\&id_territori=CA09.

${ }^{5} \mathrm{~A}$ systematic campaign started with the aim to convince the citizenry that this election will be a "plebiscite" that will be used to proclaim independence if the secessionist parties reached a majority of seats at the Regional Parliament.

${ }^{6}$ https://www.parlament.cat/web/actualitat/noticies/index.html?p_id=270292616. 
ber 2017 witnessed the appearance of a new political actor amid the serious and escalating tensions that the secessionist urges had been creating on all scenarios of social and economic life: the awakening of a strong activist response among the unionist citizens. Such population segment had remained mostly expectant for years, while the secessionist wave was growing to the point of creating the impression of a full domination on all public areas.

The unionists were able to deploy, for the first time, big street demonstrations at downtown Barcelona that competed with the gigantic demonstrations that the secessionists had mounted repeatedly on important occasions (Tobeña, 2017a; Crameri, 2014, 2015). On October $8^{\text {th }} 2017$, a week after the second illegal pseudo-referendum of self-determination, hundreds of thousands of non-secessionists claimed for the continuity of Spanish rule within Catalonia and for the closure of secession attempts. On October $29^{\text {th }}$, two days after the formal declaration of independence by the Regional Parliament and the subsequent suspension of the Autonomy Rule, another street demonstration against secession, at the center of Barcelona, was even larger and gathered most of the leaders of the unionist parties that had previously shown important differences between them. So, when the signs of an impending social and economic wreck were close enough, in the event of a secession accompanied by an automatic exit from the European Union, the crouched non-secessionist citizenry reacted openly and massively.

\section{A Recognizable Ethnopolitical Frontier}

Departing from the publicly available statistics provided by the CEO "Political barometer" of June-July $2017^{7}$ (the official Survey agency of Catalonian Regional Government), Kiko Llaneras presented a depiction of relevant socioeconomic factors, among Catalan citizenry, that were behind the options in favour of or against secession (Llaneras, 2017). The original data came from 1500 personal interviews that formed a well stratified sample covering the whole population of the region. Figure 1 shows that secession appealed mostly to native Catalans: preference for independence was superior only for those citizens born in Catalonia and with at least one parent born also there, and such preference was maximal (75\%) fort those with a long family descent within the region. On the contrary, among citizens coming from abroad, from other Spanish regions or born in Catalonia but from migrant parents, secession was not attractive at all.

These results were an exact replication, in fact, of previous analyses done with the results from the Regional elections of September 2015: the same type of family divisions predicted either voting for secessionist parties or non-secessionist parties $^{8}$. Catalan society is thus divided by independence aspirations, but that

${ }^{7}$ Barómetro de Opinión Política June-July 2017: one of the regular series of surveys about political issues that publishes the C.E.O.-Centre d'Estudisd'Opinió, Autonomous Government of Catalonia, http://ceo.gencat.cat/ca/barometre/detall/index.html?id=6288, making the data publicly available, as well as the description of the characteristics of the survey.

${ }^{8}$ https://www.racocatala.cat/forums/fil/196680/grafica-reveladora-politicament-incorrecta-dels-vota nts-segons-ceo?pag=1 (data from: CEO Political barometer 2015-3, October). 


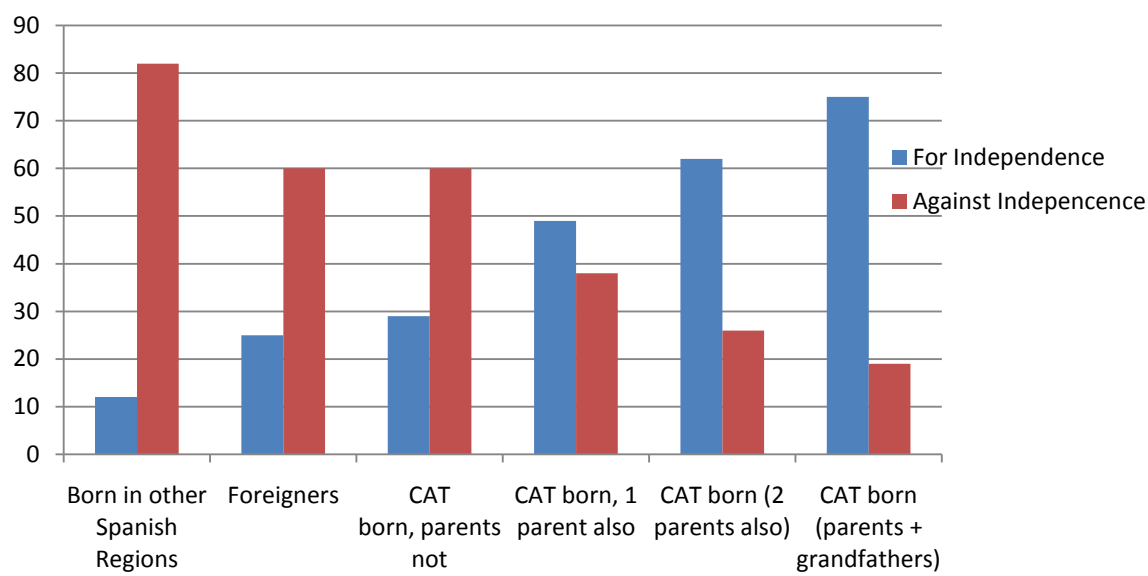

Figure 1. People in favor or against Catalonian independence (in percentages), in relation to their familial origin (CAT Born: Born in Catalonia). Adapted from Llaneras (2017), from available statistics provided by the June 2017-CEO "Political barometer" (Barómetro de Opinión Política June-July, 2017). Remnants correspond to non-responders, in each category.

fracture depends on family of origin and also on income level as Figure 2 and Figure 3, clearly show. Only $30 \%$ of Catalans with monthly incomes below $900 €$ or between $900 €-1200 €$, were in favor of independence. Those with the highest incomes were the ones that supported it. The secessionists were the majority from $1800 €$ monthly rents upwards. Among those who earned more than $€$ 4000/month, 54\% wanted the independence of Catalonia.

The gap becomes evident when people were asked about their economic situation (Figure 3). Independence was the majority option only among those who responded "we live comfortably". Among people with "many difficulties" to sustain themselves, only one third of them were secessionists.

In addition to that, the non-secessionist option was more frequent among the unemployed, the retired and the people who declared themselves of "low" or "medium-low" income. The independence was more popular, on the other hand, among public servants and also among people with college or graduate degrees, variables indicative of social class and predicting higher rents (Figure 4). Both factors, familial origin and economic income, were inter-correlated: Catalans born in another Spanish region had the lowest incomes: 37\% earned less than $€$ 1.200 /month and only $10 \%$ reached $€ 2.400 /$ month of family income. For descendants of Catalan native families, these figures were much better: only $20 \%$ earned less than $€ 1.200$ /month and up to $25 \%$ earned more than $€ 2.400$ /month (Llaneras, 2017).

The non-secessionist segment of Catalan society is highly heterogeneous though the non-fully assimilated migrants from other Spanish regions and Latin America predominate. They live in towns that make up the industrial rings of Barcelona and Tarragona's conurbations, as well as in other suburban neighborhoods and villages across the network of medium-sized towns scattered through the region. On the regional elections of $27^{\text {th }}$ Sept. 2015, a liberal-center 


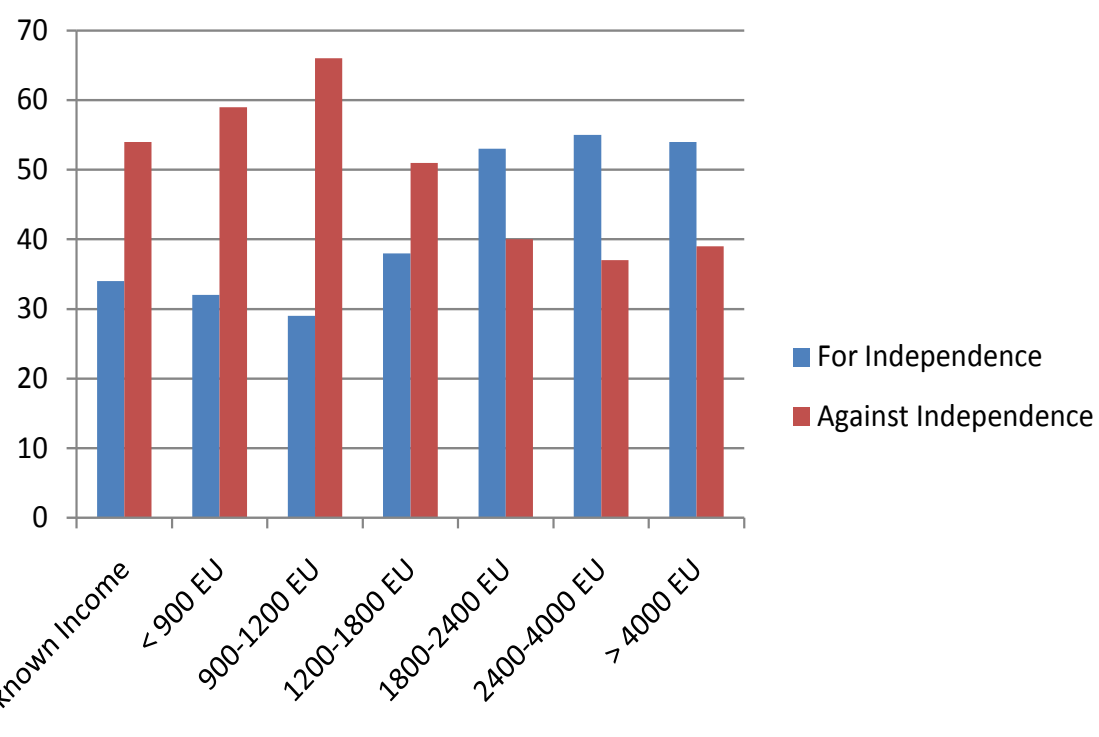

Figure 2. People in favor or against Catalonia Secession (in percentages) depending on declared monthly incomes in Euros (EU). Adapted from Llaneras (2017), from available statistics provided by the June 2017-CEO “Political barometer" (Barómetro de Opinión Política June-July, 2017). Remnants correspond to non-responders, in each category.

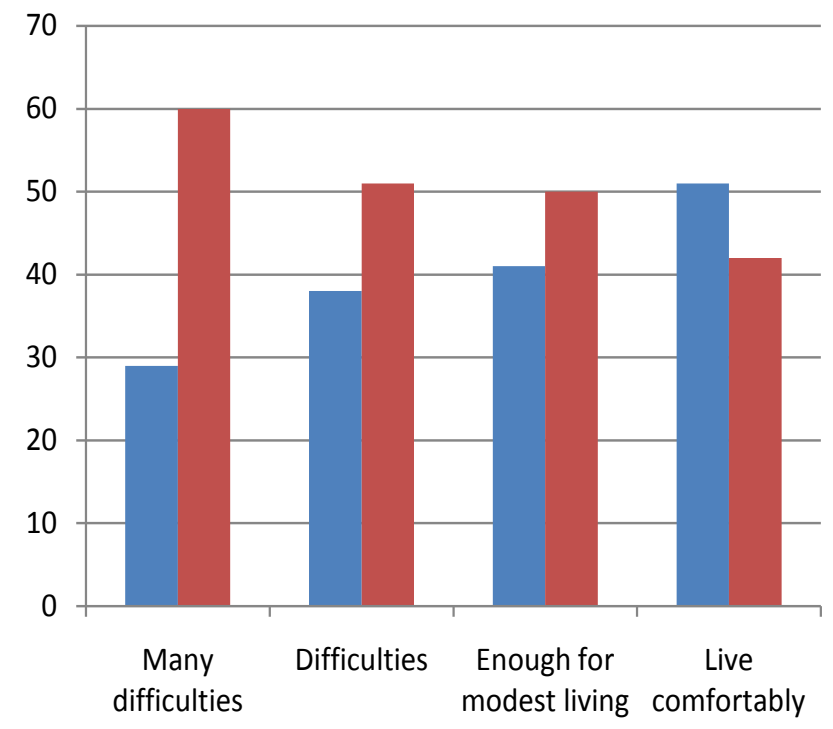

- For Independence

Against Indpendence

Figure 3. People in favor or against Catalonian independence (in percentages), in relation to the declared hardship to subsist according to their monthly incomes). Adapted from Llaneras (2017), from available statistics provided by the June 2017-CEO "Political barometer” (Barómetro de Opinión Política June-July, 2017). Remnants correspond to non-responders, in each category.

party "Citizens", with a strong unionist agenda, became the leading force of opposition at the Regional Parliament as a result of its victory on towns and neighbourhoods were that population was dominant. In the subsequent Spanish general elections of $20^{\text {th }}$ December 2015 and $26^{\text {th }}$ June 2016, a leftist coalition ${ }^{9}$

${ }^{9}$ Undefined on the issue of secession. 


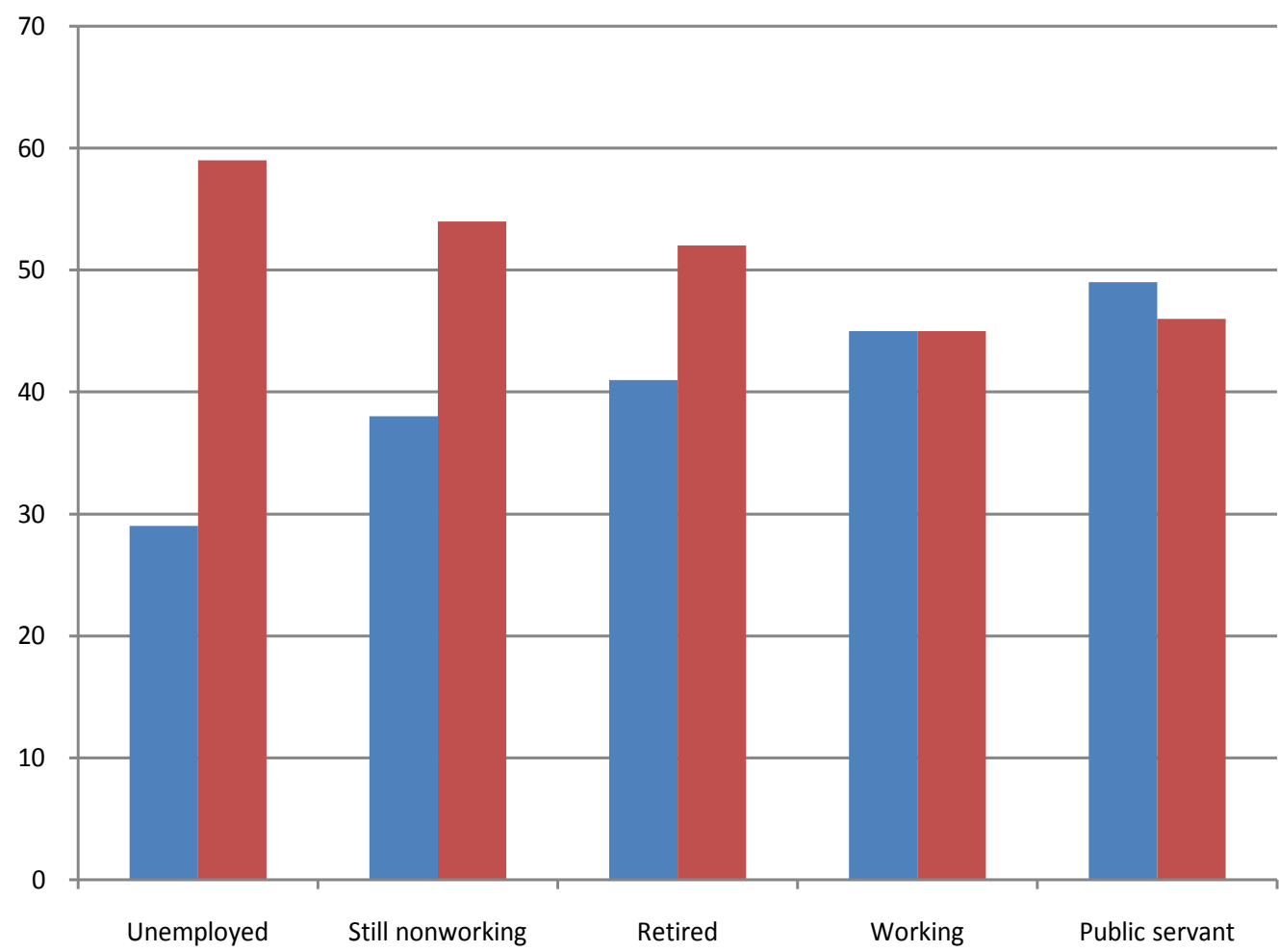

For Independence

Against Independence

Figure 4. People in favor or against Catalonian independence (in percentages), in relation to their current working situation. Adapted from Llaneras (2017), from available statistics provided by the June 2017-CEO "Political barometer" (Barómetro de Opinión Política June-July, 2017). Remnants correspond to non-responders, in each category.

("EnComú-Podem") won the majority of Catalan seats at the Madrid Parliament, collecting the bulk of votes on these sites. Despite that, at the next Regional Elections of December 21 ${ }^{\text {th }}$., 2017, "Citizens" confirmed and enlarged its previous victory of two years before, wining with such clarity on these neighbourhoods that it ended as the first force at the Catalonian Parliament.

\section{The New Strength of the Marginalized Unionists}

Those citizens had remained stoically silent across the years of the secessionist effervescence, without expressing themselves loudly through demonstrations or by exhibition of identity signs (the Spanish flag was almost absent in Catalonia, till $8^{\text {th }}$ October 2017), and this probably increased the perception that they formed a fragmented and negligible part of the citizenry. They did not have anything like strong parties or a common leadership and were politically under-represented, for decades, in Catalan Parliament, because they typically failed to appear in successive electoral contests at the regional level. They voted with turnouts similar to the rest of the citizenry at Spanish general elections, but expressed a meager interest in Catalan elections (Riba, 2000; Fernández-i-Marín \& López, 2010; Riera, 2012). But they had not bought, apparently, the glittering promises of secessionism despite the intensive apostolate received. They have been waiting still and trying to live as if there were no urgencies from the domi- 
nant secessionism. Now they have demonstrated that they can participate ${ }^{10}$ as a relevant political agent, to the point of forcing a draw. A tight draw that all opinion surveys, the turnouts at the illegal pseudo-referendums of $9^{\text {th }}$ Nov. 2014 and $1^{\text {st }}$ Oct. 2017, and the results of the previous regional elections (Autumn 2012 and 2015), had already announced (Muñoz \& Tormos, 2013; Zabalza, 2014; Tobeña, 2017).

The secessionist movement has demonstrated a robust and persisting force not only for the capacity to mobilize huge amounts of enthusiastic followers repeatedly but because it has created situations that were perceived as outstanding victories against the Central State. The successful enactment of two illegal pseudo-referendums with two million persons orderly voting for secession, were obvious defeats of the Spanish government (who tried unsuccessfully to abort them), and also for the unionist parties that dismissed their relevance. The electoral victories of secessionist parties that conferred them the majority at the Regional Parliament were undisputable successes. But the leading position attained by a unionist party (Citizens), in the election of $21^{\text {th }}$ Dec. 2017, broking a long-lived dominance of nationalist parties, combined with the fact that secessionism has never been able to surpass the threshold of $48 \%$ of voters, on three consecutive elections, consolidated a situation that has been perceived by all political actors as a draw. In addition to that, the new strength showed, at the streets, by unionist demonstrations has created a situation in which both fronts can foresee possibilities of defeat or victory, but only by very narrow margins, or the continuation of a chronic, unsolvable and entrenched draw.

\section{Will Spanish State Find a Viable Way out?}

The political tension between Spain and Catalonian secessionism is unsettled and all signs indicate that it can continue for long. There is a huge fraction of Catalan citizenry with an active secessionist agenda who knows that reaching a social majority is at hand. And there is another fraction, of similar magnitude, of Catalan citizenry that has resisted the secessionist impulse and has forced a draw on the last electoral contests. The Spanish government has persevered in being mostly static and unmovable along the whole period of the secessionist surge. It avoided entering into the political ring using tools to convince or negotiate with secessionist forces or trying to seduce their followers by other means than by warning of the serious dangers of breaking the Constitutional law. While offering an image of uneasiness, hesitation and a bit of contempt it always preferred the option of "wait and see", expecting perhaps that internal disputes among separate factions within the secessionist movement will dilute or greatly dimi${ }^{10} \mathrm{~A}$ political lobby has been created to promote a potential secession of "Tabarnia", from Catalonia, as a way of recognizing the force of the conurbations around Barcelona and Tarragona coastal areas were the Unionism is clearly dominant (Alandete D. (2017) El independentismo a través del espejo de Tabarnia, El País, 28-12-2017, (https://politica.elpais.com/politica/2017/12/26/actualidad/1514316764_370387.html); Iñaki Ellakuria (2018) Tabarnia se presentacomoespejo del “absurdoindependentista”, La Vanguardia (16-1-2018),

(http://www.lavanguardia.com/politica/20180116/4456975400/tabarnia-presentacion-espejo-absurd o-independentista-albert-boadella.html). 
nish its force. Such lack of initiative was stubbornly complemented with demands of respect for the democratic law and repeated calls to the Constitutional High Court, whenever the decisions of the Regional Government or the secessionist organizations trespassed limits ${ }^{11}$.

Once the political draw has crystallized the options for finding a viable escape to this situation seem both challenging and elusive (Lustick et al., 2004; Sorens, 2005). The secessionist movement claimed, for years, for a fully agreed and constitutionally sanctioned referendum for self-determination, but the Spanish Constitution does not permit that and potential reforms that would contemplate such kind of consultation seem now much more distant than when the crises started $^{12}$. Spain's politics will probably revolve about this conflict for long and its potential incidence within the European Union domestic struggles and difficult compromises cannot be ignored.

\section{Conclusion}

My aim in this paper has been to characterize an entrenched and tense political draw within a fractured society, in which two strongly polarized positions are confronted in favor of or against secession. These opposed preferences are intertwined with distinctive socio-economical traits among the main two segments of Catalan citizenry, and they are moreover linked to an ethno-cultural frontier based on family origins and habitual language-Catalan vs. Spanish ${ }^{13}$ (Alvarez, 2018; Tobeña, 2017a). An ethno-cultural frontier that probably contributes, as an adding factor, to the enhancing tensions. This depiction clearly departs from the rather benign or "peaceful and institutional" portraits (Griffiths et al., 2015; Crameri, 2014, 2015) that have been offered for the secessionist upsurge at Catalonia.

\section{Funding}

This essay derives from the Research Project "Sacred Values underlying Conflict Proneness: a neuroimaging study of religious and nationalist radicals", BIAL Foundation Bursary for Scientific Research 2014/2017, 163/14, to Adolf Tobeña.

\footnotetext{
${ }^{11}$ During the weeks that preceded the illegal pseudo-referendum of $1^{\text {st }}$ October 2017, the Central Government opted for coercive warnings and direct action. In addition of intelligence and vigilance operations destined to prevent the announced vote, an important deployment of police was prepared to intervene and precinct the polling stations. The journey started with clashes at different sites, at Barcelona and Girona, when police forces collided and charged against formations of resisting citizens, but afterwards the vote was allowed to continue without further interferences. A warning was then issued that any attempt to declare independence will be followed by the suspension of the Autonomy Rule and the intervention of the Region by the State. Once this was accomplished, the judiciary machine that had started to proceed under the denouncement of the General Attorney for acts of breaking the Constitutional law, applied preventive cautions and several leading secessionist politicians were sent to prison.

${ }^{12}$ The dangers of referendums for self-determination due to their demonstrated potentialities to create deep social fractures, have been systematically analysed by Qvortrup (2014) Referendums and ethnic conflict, Philadelphia: University of Pennsylvania Press.

${ }^{13}$ The Catalonian Electoral Observatory has disclosed analyses based on available statistics of C.E.O. surveys (Centre d'Estudisd'Opinió, Autonomous Government of Catalonia), showing that familial language (Catalan vs Spanish), is a main predictor of preferences for or against secession (OEC Group, SCC Barcelona, 20 ${ }^{\text {th }}$ April de 2017: "La Cataluña immune al procès" https://www.societatcivilcatalana.cat/sites/default/files/docs/La-Cataluna-inmune-vf.pdf).
} 


\section{References}

Alvarez, J. L. (2018). Els de casa frente a els de fora. El País-Opinión, 13. https://elpais.com/elpais/2018/02/12/opinion/1518460090_294017.html

Amat, J. (2015). El llarg procés: Cultura i política a la Catalunya contemporània (1937-2014). Barcelona: Tusquets.

Barceló-Soler, J. (2013). The Battle for Secession: Catalonia versus Spain. Journal of Political Inquiry, 2013, 1-11.

Boylan, B. M. (2015). In Pursuit of Independence: The Political Economy of Catalonia's Secessionist Movement. Nations and Nationalism, 21, 761-785.

https://doi.org/10.1111/nana.12121

Crameri, K. (2014). Goodbye Spain? The Question of Independence for Catalonia. Eastbourne, UK: Sussex Academic Press.

Crameri, K. (2015). Political Power and Civil Counterpower: The Complex Dynamics of the Catalan independence Movement. Nationalism and Ethnic Politics, 21, 104-120. https://doi.org/10.1080/13537113.2015.1003491

Fernández-i-Marín, X., \& López, J. (2010). Marco cultural de referencia y participación electoral en Cataluña. Revista Española de Ciencia Política, 23, 31-57.

Griffiths, R. D., Guillén Alvarez, P., \& Martínez Coma, F. (2015). Between the Sword and the Wall: Spain's Limited Options for Catalan Secessionism. Nations and Nationalism, 21, 43-61. https://doi.org/10.1111/nana.12102

Llaneras, K. (2017). El apoyo a la independencia tiene raíces económicas y de origen social. https://politica.elpais.com/politica/2017/09/28/ratio/1506601198_808440.html

Lustick, I. S., Miodownik, D., \& Eidelson, R. J. (2004). Secessionism in Multicultural States: Does Sharing Power Prevent or Encourage It? American Political Science Review, 98, 209-229. https://doi.org/10.1017/S0003055404001108

Marí-Klose, P. (2015). Un solo pueblo. El País-Opinión. https://elpais.com/elpais/2015/10/05/opinion/1444046875_755284.html

Muñoz, J., \& Tormos, R. (2013). El apoyo a la independencia de Cataluña: Identidad o cálculos económicos (No. 19)? Zoom Político. https://doi.org/10.9783/9780812209327

Qvortrup, M. (2014). Referendums and Ethnic Conflict. Philadelphia: University of Pennsylvania Press.

Riba, C. (2000). Voto dual y abstención diferencial. Un estudio sobre el comportamiento electoral en Cataluña. Revista Española de Investigaciones Sociológicas, 91, 58-88.

Riera, P. (2012). Differential Abstention in a Spain with Autonomies: Significant Traits and Explanatory Mechanisms. RevistaInternacional de Sociologia, 70, 615-642. https://doi.org/10.3989/ris.2010.10.07

Sorens, J. (2005). The Cross-Sectional Determinants of Secessionism in Advanced Democracies. Comparative Political Studies, 38, 304-326.

https://doi.org/10.1177/0010414004272538

Tobeña, A. (2017). Secessionist Urges in Catalonia: Media Indoctrination and Social Pressure Effects. Psychology, 8, 77-96. https://doi.org/10.4236/psych.2017.81006

Tobeña, A. (2017a). La pasión secesionista: Psicobiología del independentismo. Barcelona: EDLibros.

Zabalza, A. (2014). Un balance de la consulta (p. 37). El País. https://elpais.com/elpais/2014/11/19/opinion/1416415999_256355.html 